\title{
Effect of Saline Environment on the Strength of Reinforced Concrete Beams
}

\author{
Nwzad Abduljabar Abdulla \\ College of Engineering, Unversity of Salahaddin
}

\begin{abstract}
This paper presents the experimental results of tests carried out to investigate the influence of parameters such as w/c ratio, curing condition and surface bar coating on the shear and bending strengths of fifteen reinforced concrete beams under severe saline environmental conditions. Sodium chloride was used as an additive and an aqueous solution for chloride introduction. The effectiveness of coating the surface of reinforcing steel bar with a paint to protect it against corrosion in concrete was also evaluated.

Results show that after 500 days of soaking in the chloride solution the beams undergone considerable deterioration. Significant reduction in shear and flexural strength of reinforced concrete beams due to concrete degradation and steel corrosion especially when sodium chloride was used as an additive. The results indicate that the use of paint-coated reinforcing steel bars in reinforced concrete beams can be helpful to protect the reinforcement against corrosion under saline environment.
\end{abstract}

Key Words : Concrete beams, Saline environment, Water cement ratio, Shear strength.

\section{تأثير المحيط الملحي على مقاومة العتبات الخرسانية المسلحة}

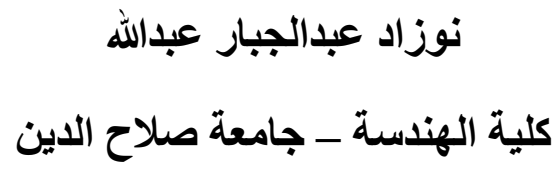

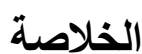

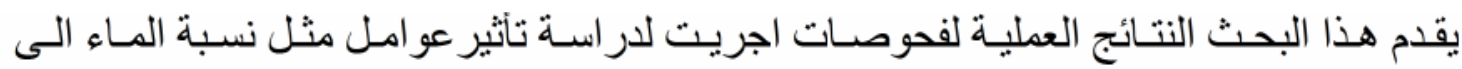

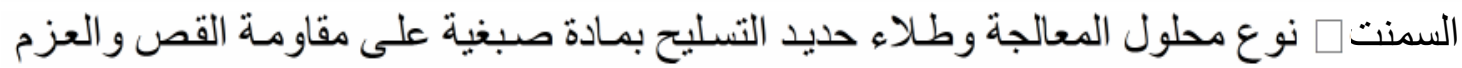

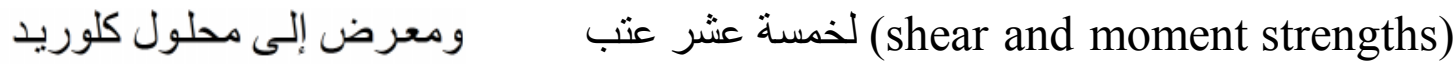
الصوديوم يمثل بيئة مالحة قاسية مشابه لبيئة البحر .يضد استعمل مـادة كلوريد الصوديوم في لئي 


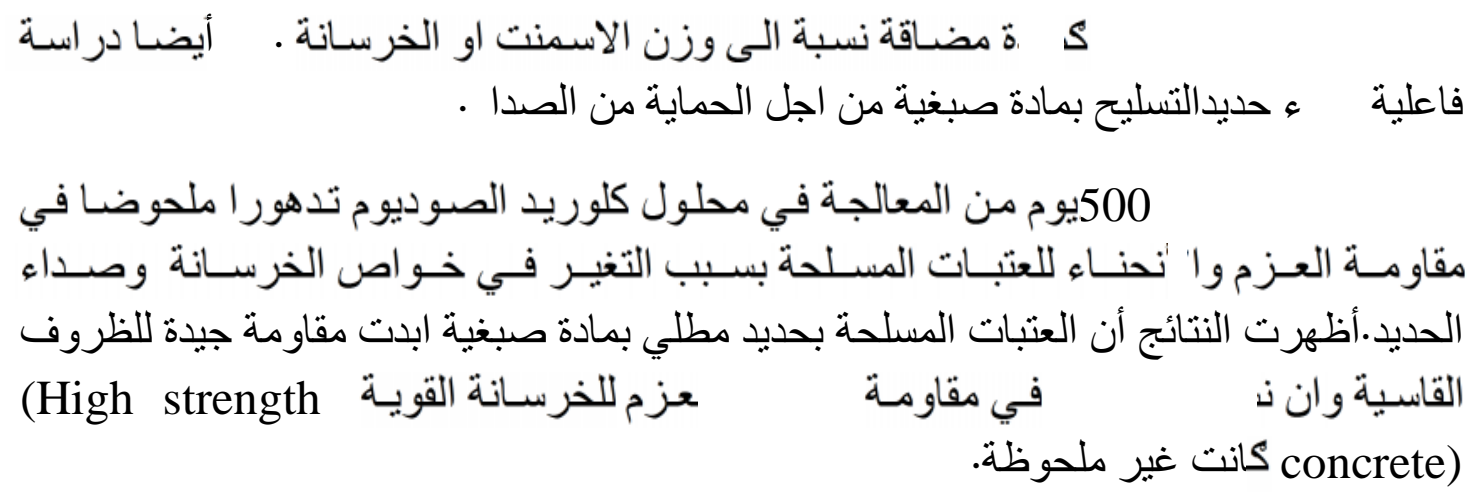

The mechanical behavior of reinforced concrete constituents depends on the resistance to deformation under external loads. Normally this resistance depends on the material properties and loading conditions. The failure criterion of such reinforced concrete is also affected by the severe environmental conditions. The protection of concrete from environmental degradation is an important durability and design concern. The mechanisms of the deterioration of a material depends on the characteristics of the material and the environment [1]. Deterioration of structural concrete may be caused either by chemical and physical environmental effects upon the concrete itself or by damage resulting from the corrosion of embedded steel. For a corroded steel bar, there is a strong interaction between the mechanical behavior of the steel bar and the surrounding environment. This interaction leads to reduction in reinforcement diameter, changes in the steel bar volume, cracks in concrete cover and modifications to the steel-concrete interface [2]. Corrosion of embedded steel is probably the major cause of deterioration of concrete structures at the present time [3]. In marine structures, 
bridges, water retaining structures and water tight basements, buildings along coastal crowded land suffer damage by chloride attack for which absorption and permeability play critical role on the durability of concrete. Steel is normally protected from corrosion when embedded in dense concrete owing to the formation of a passive film. Aggressive ions such as chloride (from road de-icing salts or sea water) are however capable of destroying the passive film. In reinforced concrete structures, cracks under service condition will lead to a gradient of chloride concentration in concrete, it is natural that the most porous medium (cracks) would be the most likely channels for chloride ingress [4].

The presence of moisture and its ability to enter and move through the concrete are the critical features since both sulphates and chlorides require moisture for mobility and alkali-aggregate reactions cannot occur in dry concrete. The development of anodic and cathodic regions on the surface of steel reinforcing bar, results in transfer of ions within the concrete cover and electrons along the bar, hence a flow of corrosion current.Many researches have attempted to study the effects of corrosion on steel or on concrete alone. But little data has been published on the joint deterioration of concrete and reinforcing steel bar in a structure. In this research the sodium chloride was used as an admixture to accelerate the corrosion of steel and degradation of the concrete so that the reinforced beams will be subjected to combined deterioration. The introduction of chloride ions into the reinforced concrete destroys the protective concrete layer on the surface of the steel, thereby initiating corrosion. Since the corrosion products occupy several times the volume of the original steel, tremendous tensile stresses are exerted on the surrounding concrete as the steel corrodes. When these stresses exceed the tensile strength of the concrete, cracking and delamination develops. The steel is then completely unprotected and the corrosion can be very fast and destructive [5].

One objective of this research is to evaluate the effect of coating the surface of reinforcing steel bar with paint in order to provide some protection to steel against corrosion in concrete. The glossy paint was built up from three layers giving a total thickness of 0.5 to $1 \mathrm{~mm}$.

\section{Experimental program}

Details of the test program are given in Table 1. Fifteen under reinforced concrete beams $(160 \times 150 \times 550 \mathrm{~mm})$ were cast using three different types of concrete, five beams for each type. Each beam specimen is singly reinforced with three deformed steel bars of $12 \mathrm{~mm}$ diameter at the bottom and two bars of $10 \mathrm{~mm}$ diameter at the top of the beam to hold the stirrups 
as shown in Fig1. Stirrups are mild steel bars of $6 \mathrm{~mm}$ diameter provided at a spacing of $70 \mathrm{nmm} \mathrm{c} / \mathrm{c}$ to resist shear stresses. Ordinary Portland cement, natural sand and $20 \mathrm{~mm}$ maximum size coarse aggregate were used for the concrete specimens. Measurements of slump according to ASTM were taken before casting the specimens. The specimens were cast in two layers on a vibrating table. Small sized beams were chosen in order to facilitate the air drying process, minimize the weight and curing space in the solution containers and to achieve quick saturation with the required aqueous solution. The steel cover on the top horizontal face of the beams was increased slightly because the surface face was hand finished and to reduce the effects of plastic and dry shrinkages and any possible bleeding. 100x200mm cylinders were prepared and tested for the compressive strength of concrete. All tested beam were cured in tap water for 28 days. After which they were air dried for 14 days. After the drying process, the beams were divided into five groups. Each group included beams made from one of the three different concrete types. Group one beams were fully cured in tap water. Group two to five were cured in $4 \%$ salt solution, which was continuously adjusted to cover the top of the beams. For Group two only, the surfaces of the steel bars were coated with three layers of glossy paint. Group three was same as Group two but without coating the reinforcement. For Group four, 2\% sodium chloride by weight of concrete was added to the mixture at the mixing stage in order to accelerate the corrosion of the reinforcing steel bars. Group five similar to Group four but using $2 \%$ salt by weight of cement. For type two a water reducer, superplasticizer (SP), was used $0.5 \%$ by weight of cement. For type three this $\%$ was increased to $2 \%$ by weight of cement.

Table 1 Concrete and steel properties

\begin{tabular}{|c|c|c|c|c|c|c|c|c|c|}
\hline $\begin{array}{c}\text { Bea } \\
\text { m } \\
\text { No. }\end{array}$ & $\begin{array}{c}\text { Mix. } \\
\text { Proport } \\
\text { ion } \\
\text { by wt. }\end{array}$ & $\begin{array}{c}\text { \%salt } \\
\text { by } \\
\text { wt.of } \\
\text { concr } \\
\text { ete }\end{array}$ & $\begin{array}{c}\text { Curing } \\
\text { solution \% } \\
\text { salt by } \\
\text { wt.of } \\
\text { water }\end{array}$ & $\begin{array}{l}\% \\
\text { SP }\end{array}$ & $\mathrm{w} / \mathrm{c}$ & $\begin{array}{l}\text { slu } \\
\text { mp } \\
(\mathrm{m} \\
\mathrm{m})\end{array}$ & $\begin{array}{l}\text { Agg. } \\
/ \\
\text { Ceme } \\
\text { nt } \\
\text { ratio }\end{array}$ & $\begin{array}{c}\text { f'c } \\
(28 \\
\text { days) } \\
\mathrm{N} / \mathrm{mm}^{2}\end{array}$ & $\begin{array}{c}\text { Steel } \\
\text { propertie } \\
\mathrm{S}\end{array}$ \\
\hline $\begin{array}{c}\text { B8- } \\
1\end{array}$ & Type 1 & 0 & 0 & 0 & \multirow[t]{5}{*}{0.62} & 50 & \multirow[t]{5}{*}{6} & 27 & \multirow{5}{*}{$\begin{array}{c}\text { Top steel } \\
\mathrm{f}_{\mathrm{y}}=470 \\
\mathrm{~N} / \mathrm{mm}^{2} \\
2 \emptyset 10 \mathrm{~T} \\
\mathrm{~A}_{\mathrm{s}}=157 \\
\mathrm{~mm}^{2} \\
\text { Bottom } \\
\text { steel } \\
\mathrm{fy}=470\end{array}$} \\
\hline $\begin{array}{c}\text { B8- } \\
2\end{array}$ & \multirow[t]{4}{*}{$1: 2: 4$} & 0 & 4 & 0 & & & & 27 & \\
\hline $\begin{array}{c}\text { B8- } \\
3\end{array}$ & & 0 & 4 & 0 & & & & 27 & \\
\hline $\begin{array}{c}\text { B8- } \\
4\end{array}$ & & 2 & 4 & 0 & & 40 & & 23 & \\
\hline B8- & & $2 *$ & 4 & 0 & & $45-$ & & 26 & \\
\hline
\end{tabular}




\begin{tabular}{|c|c|c|c|c|c|c|c|c|c|}
\hline 5 & & & & & & 50 & & & \multirow{11}{*}{$\begin{array}{c}\mathrm{N} / \mathrm{mm}^{2} \\
3 \emptyset 12 \mathrm{~B} \\
\mathrm{~A}_{\mathrm{s}}=339 \\
\mathrm{~mm}^{2} \\
\text { Stirrups } \\
\mathrm{f}_{\mathrm{y}}=270 \\
\mathrm{~N} / \mathrm{mm}^{2} \\
\varnothing \\
6 @ 70 \mathrm{~m} \\
\mathrm{~m} \mathrm{c} / \mathrm{c}\end{array}$} \\
\hline $\begin{array}{c}\text { B8- } \\
6\end{array}$ & \multirow{5}{*}{$\begin{array}{l}\text { Type } 2 \\
1: 2.2: 2\end{array}$} & 0 & 0 & $\begin{array}{l}0 . \\
5\end{array}$ & \multirow[t]{5}{*}{0.48} & 60 & \multirow[t]{5}{*}{4.2} & 41 & \\
\hline $\begin{array}{c}\text { B8- } \\
7\end{array}$ & & 0 & 4 & $\begin{array}{c}0 . \\
5\end{array}$ & & & & 41 & \\
\hline $\begin{array}{c}\text { B8- } \\
8\end{array}$ & & 0 & 4 & $\begin{array}{c}0 . \\
5\end{array}$ & & & & 41 & \\
\hline $\begin{array}{c}\text { B8- } \\
9\end{array}$ & & 2 & 4 & $\begin{array}{l}0 . \\
5\end{array}$ & & $\begin{array}{l}55- \\
60\end{array}$ & & 40 & \\
\hline $\begin{array}{c}\text { B8- } \\
10\end{array}$ & & $2 *$ & 4 & $\begin{array}{c}0 . \\
5\end{array}$ & & 55 & & 38 & \\
\hline $\begin{array}{c}\text { B8- } \\
11\end{array}$ & Type 3 & 0 & 0 & 2 & \multirow[t]{5}{*}{0.38} & 75 & \multirow[t]{5}{*}{3} & 59.6 & \\
\hline $\begin{array}{c}\text { B8- } \\
12\end{array}$ & \multirow[t]{4}{*}{$\begin{array}{c}1: 1.5: 1 \\
5\end{array}$} & 0 & 4 & 2 & & & & 59.6 & \\
\hline $\begin{array}{c}\text { B8- } \\
13\end{array}$ & & 0 & 4 & 2 & & & & 59.6 & \\
\hline $\begin{array}{c}\text { B8- } \\
14\end{array}$ & & 2 & 4 & 2 & & 70 & & 59.4 & \\
\hline $\begin{array}{c}\text { B8- } \\
15\end{array}$ & & $2 *$ & 4 & 2 & & $\begin{array}{l}70- \\
75\end{array}$ & & 59.1 & \\
\hline
\end{tabular}

$* 2 \%$ salt added by wt. of cement.

\section{Testing procedure}

All the beams were tested after a fully soaking period of 500 days. Before testing, the beams cleaned and painted white to clarify the observation of the crack propagation. The concrete surface strains at mid span were measured using demec gauges of $100 \mathrm{~mm}$ length. A central dial gauge was used to measure the mid-span deflections.

Fig. 1 illustrates the three point load positioning, reinforcement details and a cross section for a typical tested beam. The load was applied in regular increments and for each change in load the corresponding deflection and the strain gauge readings were noted. The appearance of the first crack and progress of all cracks were marked out as shown in Fig 2.

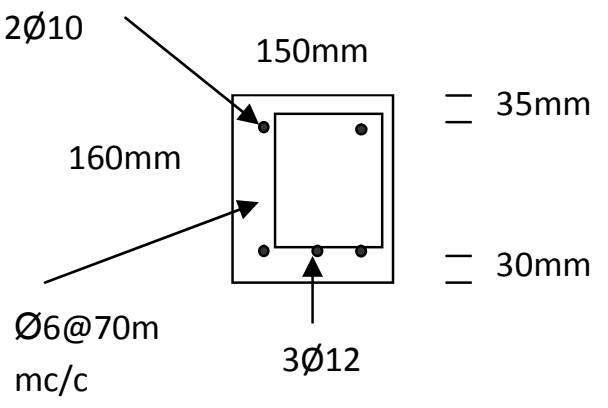




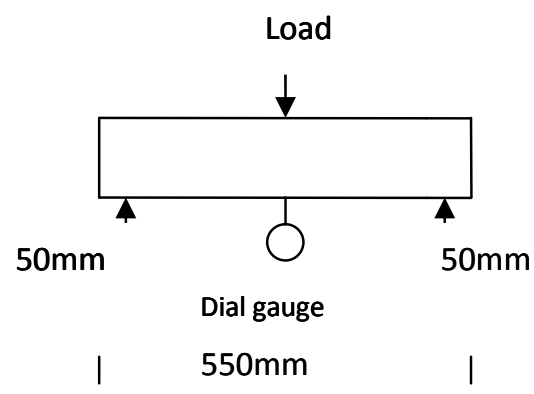

Fig. (1) Three point load positioning, reinforcement details and cross section

for a typical tested beam.
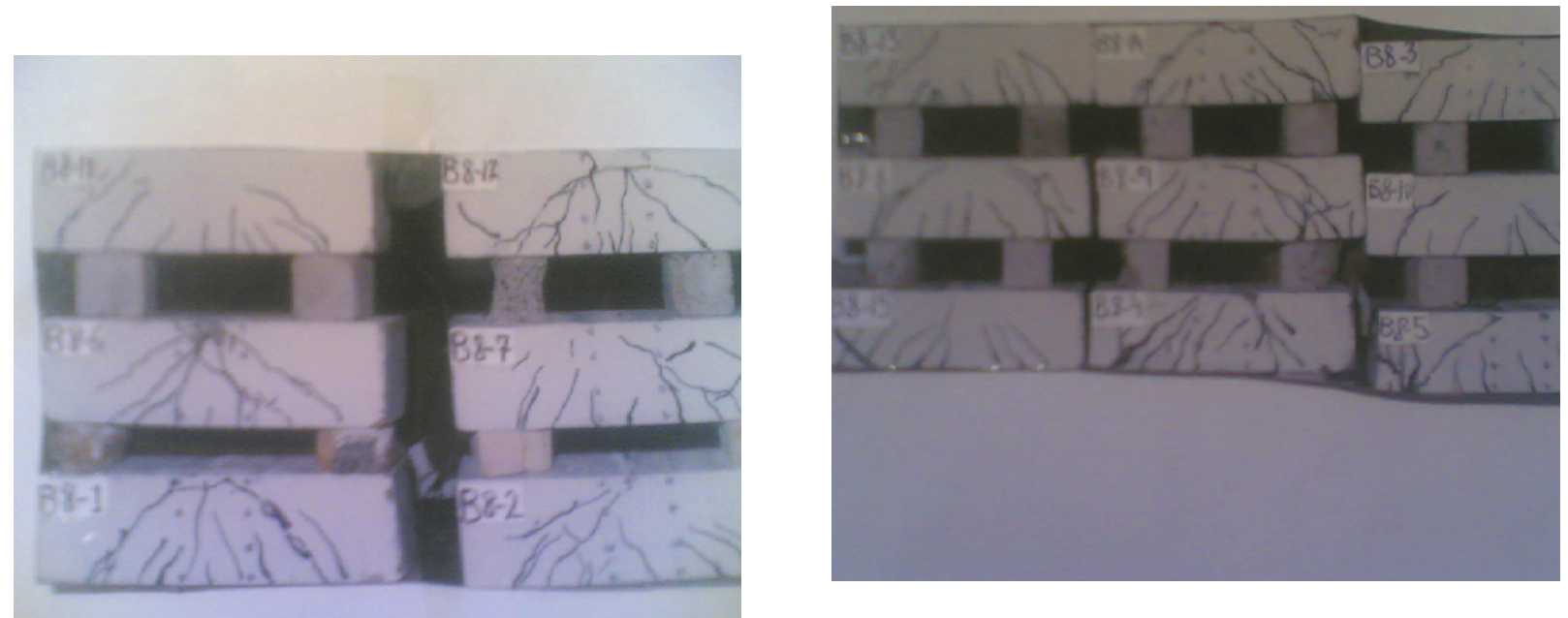

Fig.(2) Crack pattern for the five groups of tested reinforced beams.

\section{Results and discussion}

\section{Load deflection curves :}

The load-deflection relationships for the beam specimens are shown in Figs 3 through 8. It is evident that there are two clear stages; elastic uncracked and the elastic cracked zone in which 
the first crack is initiated leading to more cracks which reduce the flexural rigidity. The slope of the load-deflection curve shows significant reduction due to loss in beam stiffness as a result of extensive cracking and crack widening. The deflections at first crack and at ultimate are shown in Table 2. The Table and the curves indicate that with an increase in loading the curves shifted to the right due to slope loss of specimens soaked in sodium chloride compared with specimens soaked in water. This trend is insignificant at initial cracking deflection but more pronounced at ultimate deflection.

\section{Compressive strength :}

The compressive strengths of the tested specimens at 28 days are shown in Table1.

It is evident that the compressive strength is affected by w/c ratio and mix proportions. This strength was sensitive to the use of sodium chloride as additive resulting in significant losses for type one concrete which may be due to the leaching out of lime from the gel which has the effect of maintaining the $\mathrm{pH}$ at high levels [6].

\section{Concrete strain :}

The concrete strain was measured along the depth of most beams at midspan. Above the neutral axis the measured strains were linear across the depth at small loads. Below the neutral axis, the measured strain readings were scattered due to cracking of concrete. Strains of beams soaked in saline solution were larger than those of beams soaked in water for the same period. After a soaking period of 500 days in $\mathrm{NaCl} 2$ solution the average maximum compressive strain on the top of beams fiber of groups four and three were equal to 1.14 and $1.0810-3 \mathrm{~mm} / \mathrm{mm}$ respectively whereas for group one it was approximated to be $1.03 \times 10-3 \mathrm{~mm} / \mathrm{mm}$. The increase in strain due to soaking in $\mathrm{NaCl} 2$ solution was 11 and $5.5 \%$ for groups four and three respectively. The increase in strain of reinforced concrete beams after soaking in solution may be attributed to strength reduction, bond failure at the concrete steel interface or due to the corrosion of steel. Fig.11 shows strain distribution at constant moment zone for Beams 8-1, cured in water.

\section{Visual indications :}


Some researches have used visual indications $[7,8]$ to evaluate the levels of deterioration based either on steel deterioration due to corrosion or due to concrete degradation due to flexural cracks. Visual inspection was carried out on some of the beams after testing for ultimate load capacity. For type one beams, except B8-2, some corrosion of reinforcing steel and small reductions in cross sectional areas of parts of steel bars were observed. It was evident that the initiation of corrosion was at cracked sections for all tested beams. Inspections of reinforcement for beam B8-2 show small amount of rust which can easily be removed with finger. Type two beams, except B8-6, showed small amount of rust. Beam B8-6 showed some disbonding of the coating without any corrosion. B8-14 showed an adsorbed layer of the coating paint on the metal surface and no signs of any corrosion. Generally the corrosion activities along the beam follow the same patterns as the cracks.

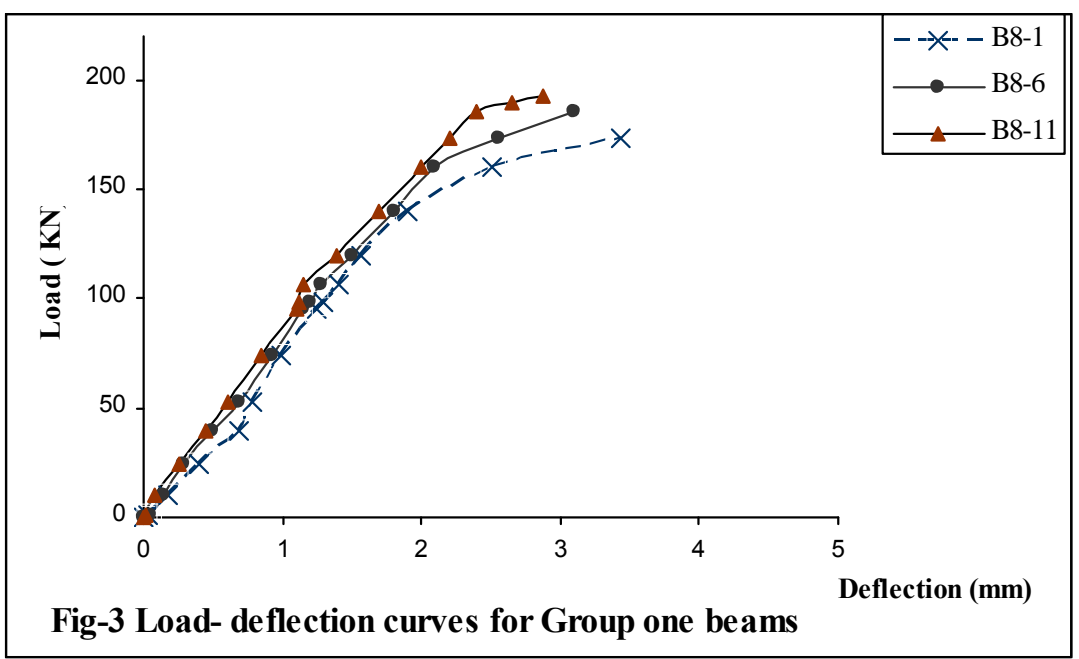




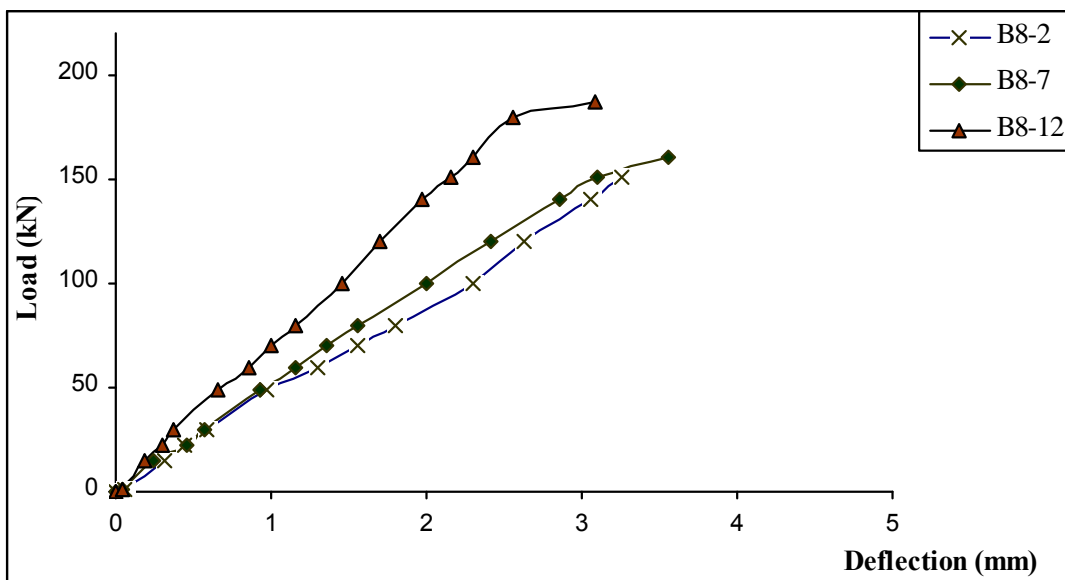

Fig-4- Laod-deflection curves for Group two beams

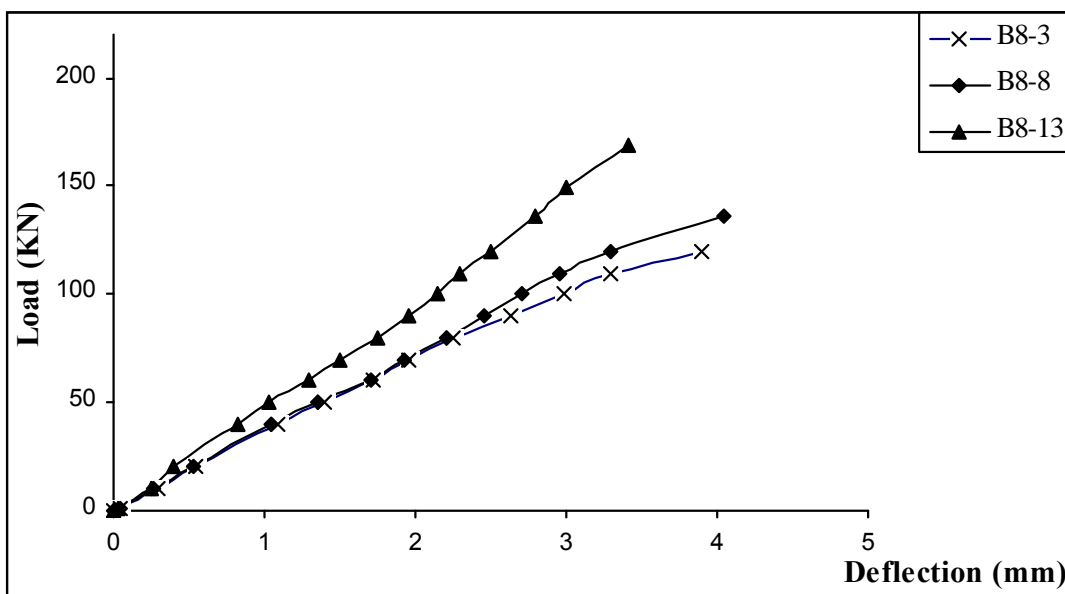

Fig-5- Load-deflection curves for Group three beams

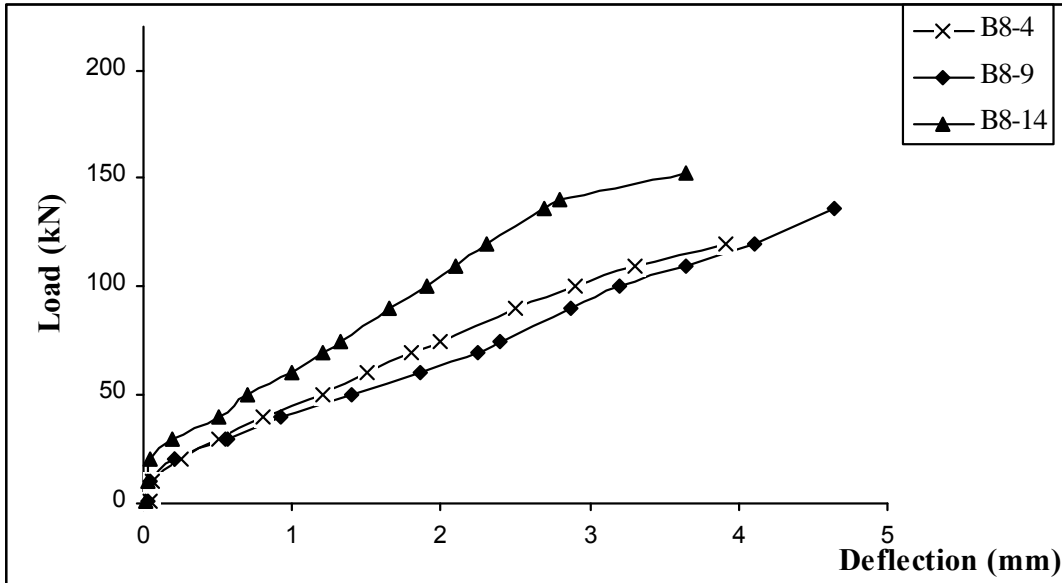

Fig-6 Load-deflection curves for Group four beams 

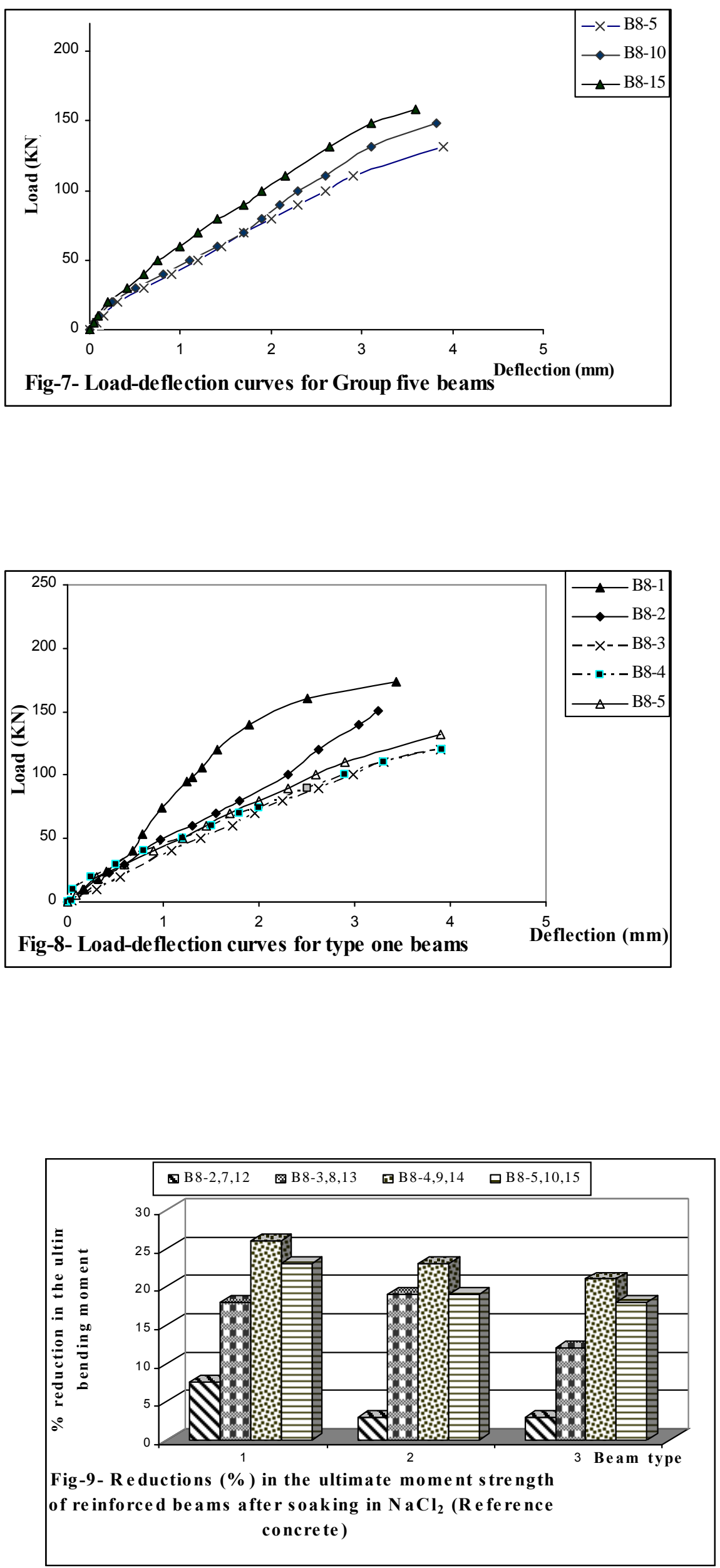

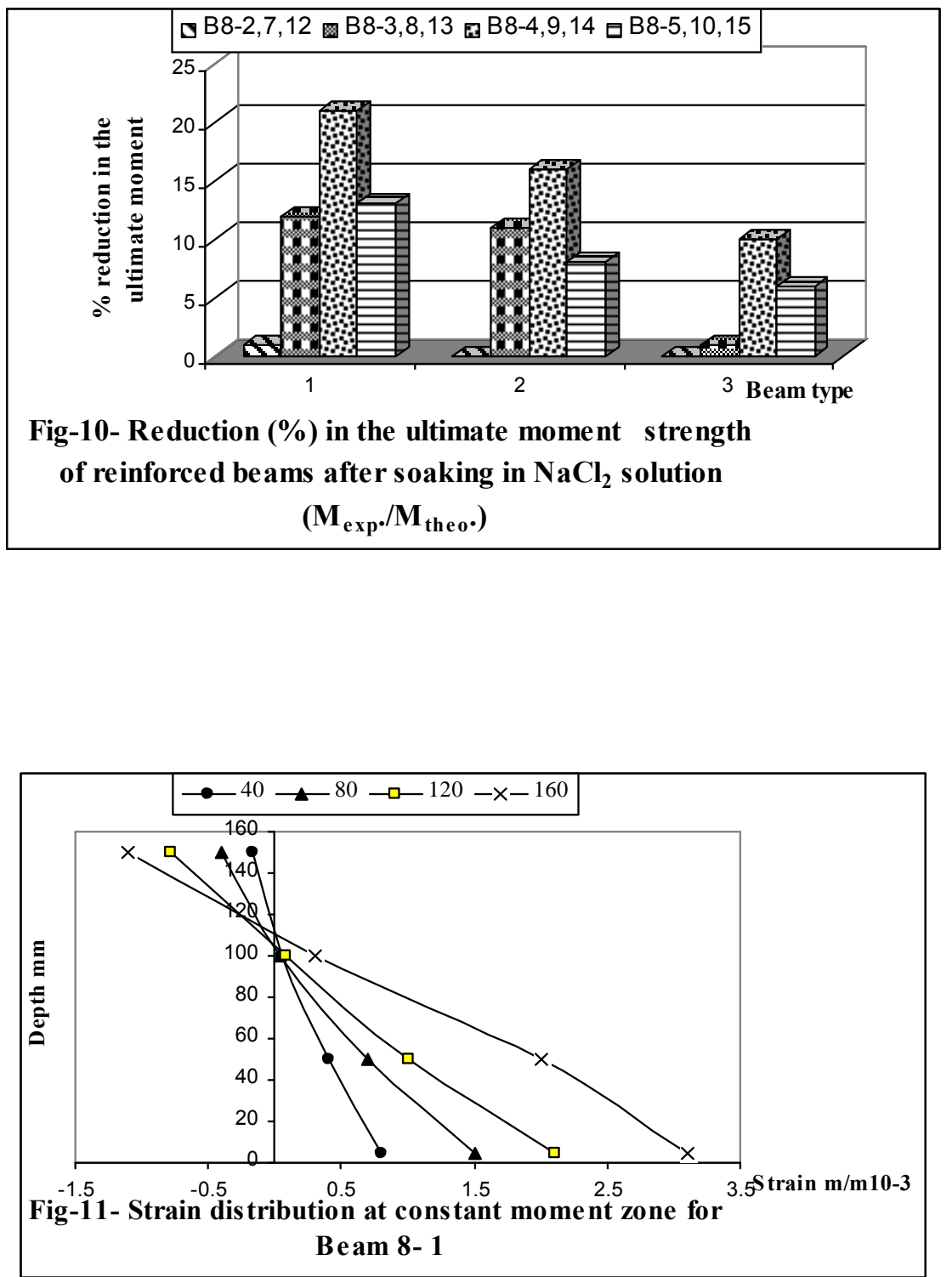

Table 2 Experimental flexural test results

\begin{tabular}{|l|c|c|c|c|c|c|}
\hline $\begin{array}{l}\text { Beam } \\
\text { No. }\end{array}$ & $\begin{array}{c}\mathrm{Mu}_{\text {theo. }} \\
\mathrm{KN} . \mathrm{m} \\
(1)\end{array}$ & $\begin{array}{c}\mathrm{cr} \\
(\mathrm{mm})\end{array}$ & $\begin{array}{c}\mathrm{Mcr} \\
\mathrm{KN} . \mathrm{m}\end{array}$ & $\begin{array}{c}\mathrm{u} \\
(\mathrm{mm})\end{array}$ & $\begin{array}{c}\mathrm{Mu}_{\text {exp. }} \\
\mathrm{KN} . \mathrm{m} \\
(2)\end{array}$ & $\begin{array}{l}\mathrm{Mu}_{\text {exp. }} / \\
\mathrm{Mu} \text { theo. } \\
(2) /(1)\end{array}$ \\
\hline B8-1 & 17.20 & 0.92 & 5.97 & 3.44 & 18.40 & 1.07 \\
\hline B8-2 & 17.20 & 0.90 & 5.91 & 3.25 & 17.00 & 0.99 \\
\hline B8-3 & 17.20 & 0.85 & 4.80 & 3.69 & 15.10 & 0.88 \\
\hline B8-4 & 16.97 & 0.78 & 4.21 & 3.92 & 13.50 & 0.79 \\
\hline
\end{tabular}




\begin{tabular}{|l|l|l|l|l|l|l|}
\hline B8-5 & 16.33 & 0.79 & 4.36 & 3.90 & 14.20 & 0.87 \\
\hline B8-6 & 18.32 & 1.12 & 6.05 & 3.30 & 19.98 & 1.09 \\
\hline B8-7 & 18.32 & 1.20 & 6.95 & 3.55 & 19.29 & 1.05 \\
\hline B8-8 & 18.32 & 1.03 & 5.80 & 4.05 & 16.24 & 0.89 \\
\hline B8-9 & 18.21 & 0.88 & 5.40 & 4.65 & 15.35 & 0.84 \\
\hline B8-10 & 18.08 & 0.80 & 5.44 & 3.83 & 16.24 & 0.92 \\
\hline B8-11 & 19.04 & 1.40 & 7.25 & 2.95 & 21.72 & 1.14 \\
\hline B8-12 & 19.04 & 1.31 & 8.30 & 3.08 & 21.05 & 1.10 \\
\hline B8-13 & 19.04 & 1.20 & 7.10 & 3.41 & 19.00 & 0.99 \\
\hline B8-14 & 19.04 & 1.02 & 6.80 & 3.85 & 17.10 & 0.90 \\
\hline B8-15 & 19.02 & 1.14 & 6.95 & 3.20 & 17.80 & 0.94 \\
\hline
\end{tabular}



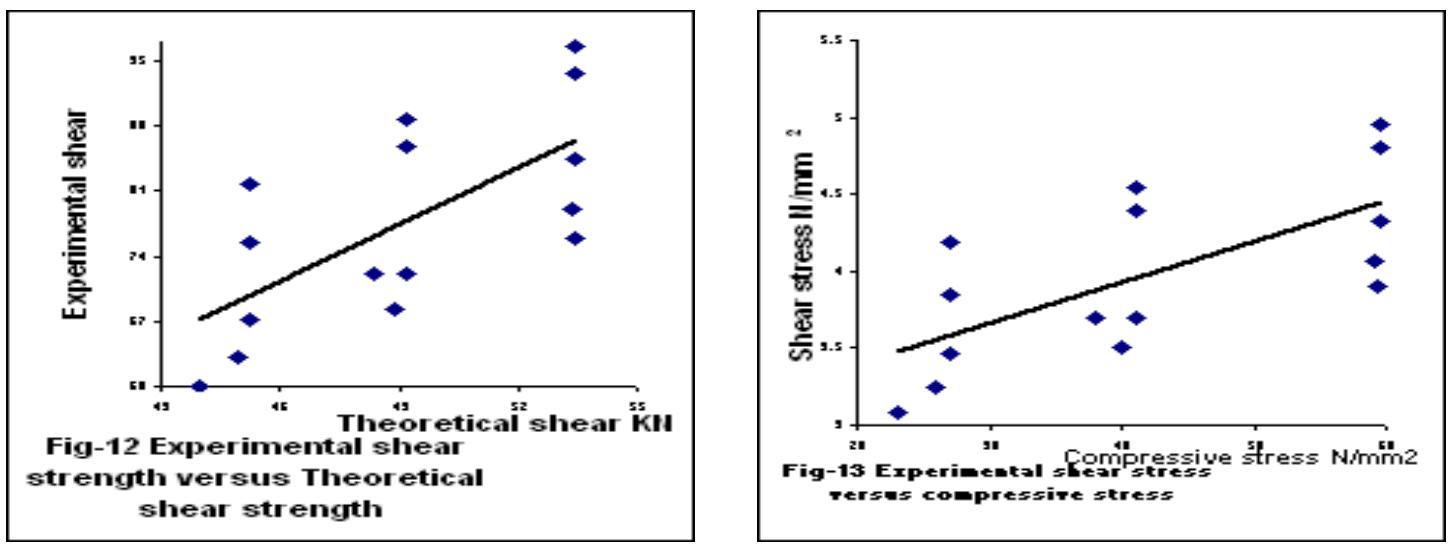

Table 3 Experimental shear test results

\begin{tabular}{|c|c|c|c|c|c|c|}
\hline $\begin{array}{l}\text { Bea } \\
\text { m } \\
\text { No. }\end{array}$ & $\begin{array}{c}\sqrt{ } f^{\prime} c \\
b_{w} d / 6 \\
(A C I) V_{c} \\
\text { KN (1) }\end{array}$ & $\begin{array}{c}\mathrm{V}_{\mathrm{s}}=\mathrm{A}_{\mathrm{v}} \mathrm{f}_{\mathrm{y}} \mathrm{d} / \\
\mathrm{s} \\
(\mathrm{ACI}) \mathrm{V}_{\mathrm{s}} \\
\mathrm{KN}(2)\end{array}$ & $\begin{array}{c}\mathrm{V}_{\mathrm{n}}= \\
\mathrm{V}_{\mathrm{c}}+\mathrm{Vs} \\
\mathrm{KN}(3)\end{array}$ & $\begin{array}{c}\text { Applie } \\
\text { d load } \\
\mathrm{P}_{\mathrm{u}} \\
\mathrm{KN} \\
(4)\end{array}$ & $\begin{array}{l}\text { Applied } \\
\text { Shear } V_{\mathrm{u}} \\
\mathrm{KN}(5)\end{array}$ & $\begin{array}{l}\mathrm{V}_{\mathrm{u}} \\
\text { Exp } / \\
\mathrm{V}_{\mathrm{u}} \\
\text { Theo. } \\
(5) /(3 \\
\text { (3) }\end{array}$ \\
\hline B8-1 & 16.89 & 28.37 & 45.26 & 163.50 & 81.75 & 1.80 \\
\hline B8-2 & 16.89 & 28.37 & 45.26 & 151.13 & 75.56 & 1.67 \\
\hline B8-3 & 16.89 & 28.37 & 45.26 & 134.24 & 67.12 & 1.48 \\
\hline B8-4 & 15.59 & 28.37 & 43.96 & 120.01 & 60.00 & 1.36 \\
\hline B8-5 & 16.57 & 28.37 & 44.94 & 126.24 & 63.12 & 1.40 \\
\hline B8-6 & 20.81 & 28.37 & 49.18 & 177.62 & 88.81 & 1.80 \\
\hline B8-7 & 20.81 & 28.37 & 49.18 & 171.46 & 85.73 & 1.74 \\
\hline B8-8 & 20.81 & 28.37 & 49.18 & 144.36 & 72.18 & 1.46 \\
\hline B8-9 & 20.55 & 28.37 & 48.92 & 136.46 & 68.23 & 1.39 \\
\hline $\begin{array}{l}\text { B8- } \\
10\end{array}$ & 20.03 & 28.37 & 48.40 & 144.36 & 72.18 & 1.49 \\
\hline B8- & 25.10 & 28.37 & 53.47 & 193.06 & 96.53 & 1.80 \\
\hline
\end{tabular}




\begin{tabular}{|l|c|c|c|c|c|c|}
\hline 11 & & & & & & \\
\hline $\begin{array}{l}\text { B8- } \\
12\end{array}$ & 25.10 & 28.37 & 53.47 & 187.10 & 93.55 & 1.75 \\
\hline $\begin{array}{l}\text { B8- } \\
13\end{array}$ & 25.10 & 28.37 & 53.47 & 168.88 & 84.44 & 1.58 \\
\hline $\begin{array}{l}\text { B8- } \\
14\end{array}$ & 25.05 & 28.37 & 53.42 & 152.00 & 76.00 & 1.42 \\
\hline $\begin{array}{l}\text { B8- } \\
15\end{array}$ & 24.98 & 28.37 & 53.35 & 158.22 & 79.11 & 1.48 \\
\hline
\end{tabular}

\section{Flexural strength :}

Although most of the beams failed in diagonal shear because they were short and shallow, the theoretical and experimental moments of the tested beams werecalculated in order to increase the data collected from this research and to provide a meaningful comparison, are given in Table 2. For water cured beams the moment strength increased as the w/c ratio decreased due to continuous cement hydration as a result of long contact with water. The incorporation of salt as an additive resulted in considerable reduction in the bending moment capacity due to strength loss. The beams cast with normal strength concrete (B8-3, B8-4, B8-5) suffered the highest degradation of bending strength. For beam B8-4 there was a considerable reduction in the theoretical moment which was due to higher $w / c$ ratio resulting in a porous concrete. The interconnection between these pores facilitates for moisture to transport oxygen and chloride ions within the concrete. These pores reduce the strength of concrete and assist in the initiation of corrosion leading to joint deterioration of steel and concrete in the structure [9]. For beams containing $2 \%$ salt by weight of concrete (B8-4, B9-9 and B8-14), the measured moment strengths were reduced by $(26,23$ and $21 \%$ ) respectively, relative to those for the corresponding control beams (B8-1, B8-6 and N8-11) due to improved concrete conductivity as a result of using salt and reduction in the stiffness of the beams. Similar trend was observed for beams incorporating $2 \%$ salt by weight of cement but with less reduction in the bending moment strength. The effect of soaking solution ( $4 \%$ salt by weight) on the flexural strength of the tested beams is more apparent in group there of the tested beams. The deterioration was $(18,19$ and $12 \%)$ when compared with the corresponding group one 
beams.The performance of group two after exposure to the soaking solution compared with the other three groups was better. For beam B8-2 there was a negligible reduction in the moment compared with the theoretical value due to the coating of steel. The coating physically blocks chloride ions but not entirely because that depends on the quality of the surrounding concrete [10]. The poor quality of the concrete reduced the effectiveness of the coating paint to protect steel completely from the corrosion. When beam B8-2 compared with the reference beam (B8-1) the percentage of reduction was only $7.6 \%$ compared with $(8,26$ and $23 \%$ ), respectively for the other beams of group one. This could be partly due to some bond failure as a direct result of using the glossy paint and largely due to the degradation of the poor quality concrete (lower strength). When considering the effect of soaking solution (B8-3) the improvement in the moment capacity $\left(\mathrm{Mu}_{\mathrm{Exp}} / \mathrm{Mu}_{\mathrm{Theo}}\right.$ ratio) equaled to $11 \%$. For groups two and three (B8-7 and B8-12) there was a further reduction in the deterioration of the beams due to the contribution of concrete .The high strength, dense matrix and lower porosity produced by using a superplasticizer reduced the rate of mobility of chloride ions [11]. The coating of the surface of steel was beneficial in reinforced concrete beams due to the formation of an adsorbed layer on the metal surface which can reduce the effects of chemical reaction in the vicinity of adsorption[12 ].The visual inspection of B8-15 confirmed the above finding. When compared with the theoretical value there was $10 \%$ increase in the bending capacity of beam B8-15 which might be ascribed to the joint protection of steel produced by coating steel and concrete [13]. The influence of parameters considered in the tests and the resulting deterioration in the reinforced concrete beam due to soaking in the saline solution was more evident in Fig.9. The figure shows the percentage reduction in the calculated moment capacity ofreinforced concrete beams after soaking in $\mathrm{NaCl}_{2}$ solution compared with the strength of reinforced concrete beam cured in water for the same Group. The percentage of reduction in the ultimate moment capacity of reinforced concrete beam after soakingin $\mathrm{NaCl}_{2}$ solution calculated from the ratio of $\left(\mathrm{Mu}_{\text {exp }} / \mathrm{Mu}_{\text {Theo }}\right.$ ratio) compared for each group with the corresponding value of beam cured in water are shown in Fig.10. 


\section{Shear strength :}

The typical crack patterns of tested beams are shown in Fig.2. In all the specimens flexural cracks were initiated at low loads. As the applied load was increased other vertical cracks appeared on the beam surface which with increasing load became inclined and propagated towards the concentrated load, forming what is known as diagonal crack. The ultimate load carried by the beam was considerably higher thanthe load at which the diagonal crack was first formed. Nearly all the beams showed the diagonal shear failure which is the mode of failure in shear. Beams B8-6 and B8-4 showed some combination of shear and crushing. Whereas beams B8-8 and B8-3 showed considerable flexural cracks before failure in diagonal tension. Thebeams cast with low compressive strength of concrete exhibited a great number of cracks. According to the ACI Building Code[14] a portion of the shear is assumed to be provided by the concrete and the remainder by the shear reinforcement :

$\mathrm{V}_{\mathrm{n}}=\mathrm{V}_{\mathrm{c}}+\mathrm{V}_{\mathrm{s}}$-------- $\mathrm{Eq}(11-2)$. In terms of Eq (11-3) and Eq (11-17),

Eq (11-2) becomes $V_{n}=ل_{f_{c}^{\prime}} b_{w} d / 6+A_{v} F_{y} d / s$

for reinforced concrete beams with web reinforcement. The measured shear strengths were compared with the nominal shear strengths predicted by the ACI 318-95[14] as shown in Table 3 and Fig. 12. The shear reinforcement contributes little during the formation of flexural cracks as can be seen from the results, the shear resisted by the concrete is equal to $35-47 \%$ of the shear resisted by the steel.The steel increases theshear capacity of the beam when diagonal cracks are formed and subsequently keep them from opening. The ultimate load produced shear in excess of the shear strength of the concrete itself. Clearly the additional shear strength was provided by the shear steel. In this research the theoretical shear carried by the stirrups are less than the experimental and the additional strength might be attributed to the longitudinal steel ratio. For all the tested beams the ACI provisions for predicting the shear strength underestimates the individual capacities provided by the concrete and by 
the reinforcing steel. The considerable difference between the experimental shear strength and the theoretical shear strength could be due to the fact that the ACI-code is design code and it's normally conservative. Also may be due to the effect of longitudinal reinforcement ratio which is conservatively not incorporated in the design requirements of the ACI building code for reinforced concrete beams having longitudinal steel ratio greater than one percent as was explained by severalresearches [15-19]. The shear strength of type one beams was reduced by $27 \%$ after the exposure to the curing solution compared with $21 \%$ for type three beams. Fig-13 shows the shear strength-compressive strength graph for the tested beams. No attempt was made to develop expression for predicting the bending moment and shear strength of beams after exposure to soaking solution because such an attempt needs extensive electro-chemical tests to determine the rate of corrosion at testing time in parallel with the flexural and shear testing of the beams.

\section{Conclusions}

1-For type one concrete there was considerable reduction in compressive strength when salt was used as an additive. For richer mixes, (type two and three) the reduction was smaller.

2-For the observed crack patterns of the beams the effect of exposure to the saline solution on the number of cracks were insignificant.

3-The incorporation of salt as an additive resulted in considerable loss in shear strength of the reinforced concrete beams.

4-The incorporation of salt as an additive resulted in considerable loss in shear strength of the beams.

5-The beams with coated steel bar exhibited greater efficiency and lower reduction in the shear strength and the ultimate moment strength when exposed to the soaking solution.

6-The effect of soaking solution on the tested beams decreased with increase in the strength of the beams. 
7-Type three beams performed slightly better than the other two types in resisting the applied shear and bending moment after exposure to the soaking solution.

\section{References}

1-Podvolny, M.A., "Mechanism of deterioration of concrete under severe environment, "proceeding of the International conference on concrete under severe conditions, CONSEC'95, Sapporo, Japan, pp. 1468-1477, (1995).

2-Coroneli, D., "corrosion cracking and bond strength modeling for corroded bars in reinforced concrete," ACI Structural journal, V.99, No.3, May-June, pp.502-510, (2001)

3-Palsson, R., and Mirza, S., "Mechanical response of corroded steel reinforcement of abandoned concrete bridge," ACI Structural journal, V.99, No.2, March-April, pp.157-162, (2002)

4-Goltermann, P.,"Chloride ingress in concrete structures: Extrapolation of observation," ACI Structural journal, V.100, No.2, March-April, pp.114-119. (2001)

5-Bennett, J.E., Martin, B.L., ARASE, K., and Kawamata, K.," Cathodic protection in North America: field results in high and low temperature environment." proceeding of the International conference on concrete under severe conditions, CONSEC'95, Sapporo, Japan, pp.1468-1477, (1995).

6-Gani, M.S.J.," Cement and Concrete, "Chapman and Hall, London, U.K, pp.212, (1997)

7-Li, C.Q., "Initiation of chloride-induced reinforcement corrosion in concrete structural members-experimentation, "ACI Structural journal, V.98, No.4, July-August, pp.502-510, (2001) 
8- Andrade, C.; Alonso, M.C., and Gonzalez, J.A.," an initial effort to use the corrosion rate measurement for estimating reinforcing bar durability," ASTM symposium on corrosion rate of reinforcement in concrete,(1988)

9-Okada, K., Kobayshi, K, and Miyagawa, T.,"Influence of longitudinal cracking duo to reinforcement corrosion on characteristics of reinforced concrete members," ACI Structural journal, March-April, pp.134-140, (1988)

10-Li, C.Q., "Initiation of chloride-induced reinforcement corrosion in concrete structural members-prediction, "ACI Structural journal, V.99, No.2, March-April, pp.133-141, (2002)

11-Li, C.Q., Zheng, J, J., and Shao, L., "New solution for prediction of chloride ingress in reinforced concrete flexural members," ACI Structural journal, V.100, No.4, July-August, pp.319-325.(2003)

12-CHO, O.C., Hong, G.S., Hong, Y.K., and Shin, Y.S., "Evaluation of epoxy coated reinforcing bars to solve the corrosion problem," proceeding of the International conference on concrete under severe conditions, CONSEC'95, Sapporo, Japan,

pp.1468-1477, (1995).

13-Mangat, P, S., and Elgraf, S., "Flexural strength of concrete with corroding reinforcement," ACI Structural journal, V.96, No.1, JanuaryFebruary, pp.502-510. (1999).

14-ACI committee318,"Building Code Requirements for reinforced Concrete (ACI318-95) and Commentary-(ACI318R-95),"American concrete institute ,Farmington Hills, Mich., pp 369, (1996).

15-Rajagopalan, K.S., and Ferguson, Phil, M.," Exploratory shear Tests Emphasizing percentage of Longitudinal Steel," ACI journal, proceedingsV.65, August, pp.634-638, (1968).

16-Placas, Alexander, and Regan, Paul, E., "Shear failure of reinforced concrete beams," ACI Journal, proceedingsV.68, No.10, October, pp.7637773, (1971). 
17-Batchelor, Barrington deV., and Kwun, Mankit, "Shear in RC Beams without Web Reinforcement," proceedings ASCE, V.107, ST5, May, pp.907-921, (1981).

18-Palaskas, M.N., Attiogbe, E.K., and Darwin, D., "shear strength of lightly Reinforced T-Beams," ACI Journal, proceedingsV.78, No.6, November-December, pp.447-455, (1981).

19- Carlos, P.R., and David, D., "shear strength of Lightly Reinforced TBeams in negative Bending," ACI Structural Journal, V.84, No.1, January-February,pp77-85, (1987). 